\title{
Russian Gas Games or Well-Oiled Conflict? Energy Security and the 2014 Ukraine Crisis
}

\author{
Thijs Van de Graaf \& Jeff Colgan
}

Whenever there is an international conflict involving a major oil or gas producer, commentators are often quick to assume a direct link between the conflict and the presence of energy resources - a phenomenon described as the 'trap of resource-determinism'. ${ }^{1}$ Things were no different in 2014 when Russia, then the world's second-largest oil and gas producer, annexed Crimea and supported separatists in eastern Ukraine. Energy has featured prominently in public discussions about the Ukraine crisis. ${ }^{2}$ Even before Russian gas deliveries to Ukraine became distorted in June 2014, the G7 energy ministers had come together in Rome to discuss ways to "disarm Russia's energy weapon," as UK Energy Minister Ed Davey put it. ${ }^{3}$ His words suggested that Russia was stirring or even masterminding the events in Ukraine by exploiting its position as the dominant gas supplier in the region. This article seeks to explore the links between energy resources and the 2014 Ukraine crisis by addressing two specific questions. Did energy help cause the crisis in the region? And, can energy be wielded as a weapon by Russia, the EU, or the US to affect the course of events in Ukraine?

We understand the term 'energy weapon' as one state's threat or action involving energy resources to compel or deter another state in the short-term. The possibility that a state might take action in the energy-sector to induce a long-term change in another state's behavior is something we consider separately, at the end of the paper.

On the causes of the crisis, we explore three potential energy-related causes. Contrary to some observers, we find little reason to believe that acquiring energy reserves or denying them to Ukraine played any significant role in Russia's decision to annex Crimea or engage in eastern Ukraine. Ukraine's energy reserves are insignificant compared to Russia's existing reserves, which is one of several reasons to doubt the proposition. However, we view natural gas price disputes between Russia and Ukraine as a contextual factor in the crisis. Moreover, we point out an additional energy-related factor that is overlooked by most observers: the nature of Russia as a petrostate, that is, a country which is heavily dependent on oil export revenues. Under the right conditions, oil rents can facilitate aggressive foreign policy. In this way, energy helped establish the foundations of the crisis. Geopolitical rivalry and domestic 
divisions within Ukraine were principally responsible for triggering the crisis. Turning to the dynamics of the crisis itself, we note that there are strict limits to the so-called energy weapon, whoever employs it. Russia has found that turning off the taps of natural gas exports is a rather blunt instrument, not ideally suited to extracting concessions. Conversely, the US will struggle to use its energy industry as a tool of foreign policy towards Russia in the shortor even medium-term. Table 1 summarizes our findings about energy's role in the Ukraine crisis.

Table 1. Energy's role in the Ukraine crisis

\begin{tabular}{|l|l|l|}
\hline & Hypothesized mechanisms & Evidence \\
\hline \multirow{2}{*}{$\begin{array}{l}\text { Cause } \\
\text { of the } \\
\text { conflict }\end{array}$} & Russia conquered Crimea for its oil and gas reserves & Implausible \\
\cline { 2 - 3 } & Disputes over natural gas trade spilled-over into conflict & Key contextual factor \\
\cline { 2 - 3 } & Oil wealth has made Russia more autocratic and belligerent & Key contextual factor \\
\hline \multirow{2}{*}{$\begin{array}{l}\text { Weapon } \\
\text { in the } \\
\text { conflict }\end{array}$} & Russia can cut-off its gas deliveries to Ukraine and Europe & Yes, but ineffective \\
\cline { 2 - 3 } & US LNG exports can undermine Russia's power in Europe & Depends on market forces \\
\cline { 2 - 3 } & Western energy sanctions can bring Russia to its knees & Highly unlikely \\
\hline
\end{tabular}

A full recap of the complex events that have unfolded in Ukraine is beyond the scope of this article. Suffice it here to repeat that what started as a wave of protests against former Ukrainian President Viktor Yanukovych in November 2013 steadily escalated into a conflict of global geopolitical significance. Russia annexed Crimea in March 2014 and actively supported Russophile separatists in eastern Ukraine, though Moscow repeatedly denied any involvement. After a five-month conflict between the separatists and the Ukrainian army a fragile cease-fire was agreed in early September 2014, yet shelling and skirmishes continued. By the end of November, the death toll of the conflict had already risen to at least 4,364 people, ${ }^{4}$ including 298 passengers on a Malaysian airliner traversing eastern Ukraine in July. In February 2015, a new settlement agreement was reached. Even though low-scale conflict continues, the new agreement still commands at least rhetorical support in Kiev and Moscow. For the foreseeable future, it appears that Donbass (Ukraine's eastern province) is destined to occupy a place on the list of frozen conflicts in the post-Soviet space.

The political fall-out from the crisis continues. Russia has been ousted from the G8 and NATO countries have agreed to establish a rapid-response force, capable of deploying to Eastern Europe on 48 hours' notice, combined with more military exercises and enhanced air 
patrols over the Baltic States, Poland and Romania. Western countries have also agreed on a series of diplomatic and economic sanctions against Russia, including sanctions targeting its energy sector. Moscow has responded in kind with sanctions against Western individuals and, since August 2014, a full embargo on food imports from the EU, US and other western countries.

Our analysis operates at multiple levels, considering systemic, state-level, and leaderlevel behavior and effects. No detailed analysis of a specific crisis such as this one can afford to ignore any of these levels. We show that energy resources were not the primary causes of the conflict, although they played a contextual role. Instead, the main drivers of the conflict have to do with Ukraine's contested position within Russia's sphere of influence and the orbit of European Union. Domestic politics and decisions by individual leaders also play a significant role. Broadly speaking, for Putin, the crisis was an opportunity to strengthen Russia's sphere of influence - and to bolster his own domestic popularity. For Ukraine, the conflict arose out of a determined struggle by some but not all of its people to re-orient the country towards the EU and Western ideals of governance.

\section{Is the Ukraine Crisis an Energy War?}

The continuing standoff between Russia and Ukraine is not primarily an energy battle. It is a multi-layered conflict that revolves first and foremost around power, territory, and domestic politics. Nonetheless, it is hard to fully apprehend the complex and contingent events in Ukraine as they unfold without an appreciation of the role that energy played in igniting and shaping the conflict - a crucial role, certainly, but far from a straightforward one.

To begin with, energy was no direct casus belli. True, the Crimean peninsula has significant potential offshore oil and gas reserves, which had attracted the attention of companies such as Exxon and Shell prior to the crisis. ${ }^{5}$ These potential fields now fall under the (disputed) jurisdiction of Russia, as does Chernomorneftegaz, the breakaway subsidiary of the Ukrainian state-led Naftogaz that owns several energy assets, including an underground gas storage facility with a capacity of 1 billion cubic meters. Some observers suggest that these energy resources and assets were an important part of Russia's strategic motivation in seizing Crimea. ${ }^{6}$ Yet this seems implausible. Consider the counterfactual: if Crimea had zero energy resources, would Putin still have decided to annex the territory? We think it is highly probably that he would have.

After all, Crimea is of more obvious historic, cultural, and strategic importance to Moscow than it is of economic significance. Crimea belonged to Russia from the $18^{\text {th }}$ century 
until 1954, when Krushchev gave the land to Ukraine, then a Soviet republic. The transfer was merely symbolic until the break-up of the Soviet Union in 1991. Out of its 2 million residents, nearly 60 percent identify as Russian, which is the highest concentration of Russian speakers in Ukraine. ${ }^{7}$ Crimea has historically been a naval stronghold for Russia. After the dissolution of the Soviet Union, an agreement between Russia and Ukraine allowed Russia to keep stationing part of its Black Sea fleet in Sevastopol. With these key Russian interests at stake, the presumed presence of offshore oil and gas, the size of which is still clouded in uncertainty, played a secondary role at best.

The energy assets seized in Crimea should thus be thought of as collateral benefit, rather than a deliberate strategic objective. So is the fact that the fighting in eastern Ukraine destabilizes an important Ukrainian region for shale gas. Estimates indicate that Ukraine has the third-largest shale gas reserves in Europe, behind France and Poland, ${ }^{8}$ and some of these shale fields are in eastern Ukraine. ${ }^{9}$ The current crisis ensures that Kiev's hopes of becoming more energy independent are shelved for some time. Yet exploration activity in Ukraine had been minimal anyway, and it is highly unlikely that this element influenced the calculations of Russian decision-makers when they decided to covertly support separatists in the region.

Still, it would be wrong to conclude that energy did not shape the conflict at all. Consider a second potential cause: the history of disputes over natural gas pricing. After the break-up of the Soviet Union, some (but not all) Soviet successor states continued to receive Russian gas at discount prices. This changed in the mid-2000s when Russian President Putin began to support Gazprom's desire to realign gas prices for neighboring customers with European oil-indexed prices. The steady increase in the oil prices, and therefore European gas prices, from 2003 to 2008 made the transition particularly difficult for the importers. These price increases provoked a series of 'gas wars' between Russia and key transit countries (with Ukraine in January 2006, March 2008, and January 2009; with Belarus in February 2004 and January 2007; and Moldova in January 2006). ${ }^{10}$ Ukraine, especially, was poised to exploit its pivotal transit role for Gazprom's deliveries to Europe. ${ }^{11}$ In 2004, 80 percent of Russian gas exports to Europe were still delivered via Ukraine. ${ }^{12}$ The 2009 Russo-Ukrainian gas crisis was the most severe. All Russian gas flows to Ukraine were halted for three full weeks in the middle of the winter (not just the gas molecules destined for Ukrainian consumption), with effects reverberating through Central and Eastern Europe. It was resolved when Gazprom and Naftogaz signed an 11-year contract with a price formula similar to those typically used in Gazprom's long-term contracts with its principal European customers. ${ }^{13}$ The 2009 contract 
marked a move away from the previous system whereby the gas price was negotiated bilaterally each year. ${ }^{14}$

In practice, Moscow never fully abandoned its old strategy of buying influence and allegiance through adjusted pricing of its natural gas exports. In April 2010, the contract was renegotiated and Ukraine got a significant discount on the gas price in exchange for a political concession, namely an extension of 25 years on the lease by Russia of the naval base in Crimea. When Kiev was about to sign an association agreement with the EU in November 2013, the Kremlin - through Gazprom - offered a 33\% discount on the gas import price, from $\$ 402$ to $\$ 268.5$ per 1,000 cubic metres. ${ }^{15}$ This was probably one of the main factors that lured former President Yanukovych to ditch the trade deal with Europe, triggering the Maidan protest movement that would eventually unseat him three months later.

After the ousting of Yanukovich and the annexation of Crimea, both discounts were scrapped in April 2014. As a result, gas prices for Ukraine hiked by more than 80 percent, to $\$ 485$ per 1,000 cubic meters, the highest price in Europe. Russia could unilaterally scrap the 2010 discount (obtained for the Crimean base lease) because the discount was given in the form of a suspension of export duties levied by the Russian state on gas exported to Ukraine. Gazprom was prepared to lower its price demand to $\$ 385$, broadly in line with prices for other European countries, but Kiev rejected the offer because the discount would have again been awarded in such a way that it could be undone at any time by the Kremlin. ${ }^{16}$

In short, it is hard to tell the full story of the recent political crisis in Ukraine without reference to the gas import pricing issue. Yet, the importance of the gas import price as an explanatory factor should not be overstated. While the Russian natural gas price discount probably explains Yanukovych's rejection of the EU association agreement, it does not explain why so many protestors took to the streets afterwards, why the Maidan protests turned violent, why the president fled the country, why separatists in the easts rebelled, or why Russia supported these insurgencies. In short, history might have been different at many points. Consequently, we regard natural gas disputes as a contextual factor in the dispute.

Finally we consider a third potential way in which energy paved the way for the 2014 Ukraine crisis and one that is frequently overlooked: Russia's resource curse. ${ }^{17}$ Russia's dependence on revenues from the energy sector has changed the nature of the Russian state, making it not only more susceptible to corruption and autocracy domestically, but also more likely to engage in international conflict. Oil and gas export revenues have helped ensconce Vladimir Putin as an autocrat and given him a free hand in foreign policy. 
Russia's incursion into Crimea and eastern Ukraine can be seen as a close cousin of "petro-aggression." As one of the authors has shown in previous research, a state is more likely to instigate international conflict when it has a combination of a high oil income and a leader with aggressive preferences. A lot more likely: 250 percent more military conflict than a typical non-petrostate, on average. ${ }^{18}$ Oil income means more military spending, increasing the state's scope for potential conflicts. Even more importantly, it distorts the domestic politics of the state, reducing the leader's domestic political risk from military adventurism and aggressive foreign policy. It is worth noting, however, that oil does not have a monolithic effect: there are plenty of non-aggressive petrostates, such as Nigeria, Kuwait, or Oman. Oil plays a causal role only when certain leadership conditions are met.

A narrow definition of petro-aggression focuses on the combination of oil and revolutionary leaders. ${ }^{19}$ That narrower view is based on the idea of using domestic revolutions as a proxy indicator for aggressive leaders, based on the substantial evidence that revolutionary leaders are systematically more likely to have aggressive preferences (e.g., Qaddafi, Hussein and Khomeini). ${ }^{20}$ Putin is not a revolutionary leader, but he does seem to have aggressive preferences. He has repeatedly avowed a hard-nosed, realpolitik view of the world. He has repeatedly asserted his ambition to return Russia to its status as a superpower of the first rank. Thus both conditions for petro-aggression (oil and aggressive leader) are satisfied in the case of Putin's Russia.

In sum, energy was not the sole cause of the crisis, or even its largest cause, but it did play a crucial role in setting the context within which the crisis developed, via two mechanisms: natural gas prices and Russia's petro-aggression. But how did energy affect the dynamics of the crisis itself?

\section{Limits to the Energy Weapon}

Almost as soon as the crisis was underway, commentators and policy-makers began to discuss the possibility of the "energy weapon" being used, either by Russia or by the US and Europe. In the first instance, the term "energy weapon" refers to the ability of Russia to turn off gas supplies to Ukraine or other countries dependent on Russian gas in order to pile pressure on the targeted country and defend the interests of Moscow. The gas wars with Ukraine in 2006 and 2009 are frequently interpreted along these lines, with the former seen as a Russian retaliation for the 2004 Orange Revolution and the latter as a reaction to moves by the Bush administration to begin the process for Ukraine and Georgia to become NATO members in the wake of the Russo-Georgian war of 2008. In other words, these gas wars are not seen as 
commercial disputes but as part of a calculated strategy by Russia to regain influence over countries that were once part of the Soviet empire and to roll back Western influence.

When Gazprom cut its gas deliveries to Ukraine in June 2014 pundits saw new evidence of the energy weapon being wielded unilaterally by Russia. Yet this view is too simplistic. The gas cut-off followed weeks of negotiations between the two sides, with the European Commission acting as a broker. These negotiations were obviously tangled with the broader political crisis in Ukraine, yet they revolved mostly around two key commercial points - the pricing of Ukrainian imports and the debts that Naftogaz had accumulated since September 2013 for gas delivered, but not paid for. During the negotiations, Naftogaz acknowledged (part of) its outstanding debt, while Gazprom offered a reduction on the gas price. ${ }^{21}$ The fact that the negotiations broke down in the summer (when gas demand is low) and after a mild winter (leaving ample gas storage levels in Ukraine and Europe) undoubtedly strengthened the bargaining hand of the Ukrainian side. The point here is not to blame either side but to illustrate the limits of the Russian gas weapon.

These limitations are amplified with regard to Russia's alleged stranglehold on Europe through its position as dominant gas supplier. A sustained gas embargo by Russia is not possible. Revenue from gas sales abroad is important for its state coffers - though much less than oil: while together these sectors account for about half of Russia's federal budget, Russia receives almost four times as much revenue from exports of crude oil and petroleum products as from natural gas. ${ }^{22}$ It has no alternative clients, at least not in the short term, since most of its gas exports are pipeline-bound and cannot easily be redirected. This may change somewhat because of Russia's 2014 deal to supply China with 38 billion cubic meters (bcm) of gas, starting around 2018. The agreement will likely turn China into Gazprom's secondbiggest customer, behind Germany, but it is unlikely to enable Moscow to play its eastern and western customers against each other. ${ }^{23}$ Indeed, Russia will use different gas fields to supply China than the ones it uses to supply Europe, meaning that Russia will not be able to redirect gas destined for Europe to China. And last but not least, Russia should and does worry about its reputation as a reliable supplier. The fact that OPEC's market share has never recovered from the after-effects of the 1973 oil shock illustrates the dangerous, long-term effects of energy boycotts for producers.

One of the striking features of the 2014 Ukraine crisis was that the "gas weapon" was not solely attributed to Russia, but also to the West. Within the US, for example, many commentators called for the use the country's envisaged oil and gas exports as a "geopolitical weapon" to weaken Putin's hand. ${ }^{24}$ When the US Department of Energy authorized a permit 
for an LNG project on the west coast in March 2014, this was interpreted as a "warning shot at Russia." ${ }^{25}$ Analysts often extol the recent oil sanctions against Iran, which were made possible in part because the US shale oil boom alleviated fears of a price spike, claiming that the US natural gas sector might make something similar possible against Russia. ${ }^{26}$

In spite of these assertions, the US faces severe limitations to using its natural gas exports as a weapon against Russia. The US currently does not have the export facilities to ship LNG to its European allies in any significant quantities. The first LNG export terminal in the lower-48 states, Cheniere's Sabine Pass on the border between Texas and Louisiana, only began operations in February 2016. To be sure, four additional LNG export terminals are in the making and more have been approved, nullifying this infrastructure argument in the long term. ${ }^{27}$ Even so, it is important to remember that the decision to export gas to a foreign market is not the US government's to make. Decisions are made by the energy companies that ship the gas, and LNG exports will ultimately go to the highest paying market. Most of the initial US LNG cargos went to South America, and some of it even ended up in unexpected places such as the UAE, Jordan and Kuwait. Only 2 of the 35 first LNG vessels went to Europe. ${ }^{28}$ The July 2016 opening of the expanded Panama Canal could mean more US LNG will go to Asia. Of course, new LNG supplies from the US could free up other supplies destined for Asia, which could potentially move to Europe instead. Yet they will come at a price premium compared to Russian low-cost supplies. ${ }^{29}$ Finally, many pundits argue that Russia's real vulnerability lies in the oil sector, not in the gas market. Revenue from gas sales abroad makes up 8 percent to 9 percent of the Russian budget, while oil revenue accounts for a much heftier 37 percent to 38 percent. ${ }^{30}$

The US, Europe and western partners have introduced a series of sanctions since March 2014, including sanctions against Russia's energy sector. There are some differences between EU and US energy sanctions but the tenor of the latest energy sanctions that were introduced in September 2014 is the same: it forbids western companies to supply technology or services that could aid Russia in developing its Arctic, shale, and deepwater oil reserves. ${ }^{31}$ Russia is counting on these types of unconventional resources to sustain its oil production at around 10.5 million barrels per day, amid declining output at old West Siberian fields. ${ }^{32}$

Taken as a whole, these sanctions do not appear to apply much short-term leverage on Russia, because they keep Russia's oil and gas taps open in the short- and medium-term. The sanctions do not apply to gas, they only apply to oil and more specifically unconventional oil. Their aim is not to curb current oil production in Russia but to hit future production by depriving Russian firms of the expertise of western energy majors. In addition, there are some 
loopholes in the sanctions by the EU, which relies on Russia for 30 percent and 35 percent respectively of its oil and gas consumption. For example, the European energy sanctions do not apply to agreements made before September 12, 2014. In practice this means that Exxon, BP, Shell, and Total can still cooperate with Russian companies to develop Arctic, offshore and shale formations in Russia under a contract or an agreement concluded before September 12 , or because they are principally drilling for gas. ${ }^{33}$

The energy sanctions against Russia are thus far removed from the oil sanctions that the US and the EU imposed on Iran from 2012 to 2016, which not only banned all imports to the EU but also discouraged third countries to buy Iranian oil through a series of stringent financial sanctions. ${ }^{34}$ Diplomats in Washington and Brussels are well aware that repeating this scheme with Russia would be a lot more impracticable, expensive and risky. ${ }^{35}$ Russia is a much larger oil producer than Iran was in 2011 and the EU's dependence on Russian oil is also far greater. Moreover, it is questionable whether American and European policy-makers would really want to bring the Russian economy to its knees. There are significant risks to creating a "tumbling nuclear state on Europe's doorstep." 36

The significant drop in oil prices since mid-2014, from over 110 dollars per barrel of Brent crude in June 2014 to less than 50 dollars in May 2016, has put more pressure on Russia than the sanctions. Oil prices slid due to oversupply, chiefly because of growing tight oil production in North America, and weak demand based on a slowdown in the growth of China and the Eurozone. The ruble declined, inflation soared, and its economy shrunk by $3.8 \%$ in 2015. ${ }^{37}$ The negative impact was cushioned somewhat because much of Russia's debts were in rubles, which declined as oil prices fell, but the Russian economy has been hurt nonetheless. Whether sustained oil prices in the long-term will lead Putin to adopt a more conciliatory stance toward Ukraine (because lower oil revenues weaken the domestic resource curse effect) or rather a more aggressive stance (because an external enemy could deflect attention from the country's domestic woes) remains to be seen.

While the "energy weapon" per se is ineffective, each side nonetheless pursues longterm strategic goals. Russia seeks large amounts of natural gas storage capacity in Hungary and elsewhere in Europe, which could at least theoretically give it the ability to supply European customers even if it shut down gas exports to Ukraine for a reasonably protracted period of time. ${ }^{38}$ Russia has long pursued a strategy to build alternative gas pipelines around Ukraine, for the same reason. It achieved successes with the opening of the Yamal (1997), Blue Stream (2003) and Nord Stream (2011) pipelines, yet in late 2014 Russia suffered a setback when it abandoned its plan to build the South Stream pipeline across the Black Sea to 
Bulgaria. Financing the megaproject had become more difficult given the country's economic woes and Gazprom was not willing to agree to the EU's internal market rules, which require equal third-party access to the pipeline. Instead of South Stream, Russia announced that it would build a second leg to the Blue Stream pipeline that also traverses the Black Sea and goes to Turkey. This so-called Turkish Stream project was temporarily put on hold after the downing of a Russian fighter jet that allegedly breached Turkey's airspace in November 2015. Nonetheless, in October 2016, the two countries signed an intergovernmental agreement to begin the construction of the Turkish Stream gas pipeline. Russia has also made a priority of finishing a second leg of Nord Stream, dubbed Nord Stream 2. Though very controversial, this project seems to move ahead. ${ }^{39}$

Likewise, the principal aim of the US and EU sanctions is not to reduce Russian exports in the short-term, but rather to reduce the viability of the Russian oil sector in the long term by cutting off foreign investment, similar to what has occurred in Iran since 1979. These sanctions, if maintained, would take years to have a serious effect - but that gives the rest of the world oil market time to adjust. Western policymakers are, in essence, threatening longterm pain for Russia's oil sector without causing a short-term oil shock that would be painful for the rest of the world. It is not obvious, however, that the US-EU coalition supporting the sanctions can be maintained politically, especially in the wake of the election of Donald Trump as the new US President. Russia might decide that it only needs to feign political cooperation in order to slip out of the sanctions, having consolidated its gains in Crimea and Eastern Ukraine. Still, the situation is ironic: in response to an alleged but largely fictional Russian energy weapon, the US/EU sanctions against Russia actually securitize the energy sector.

\section{Conclusions}

We argue that the Ukraine crisis was not an "energy war" as conventionally understood in the popular discourse, but energy did play a crucial role along several dimensions. On the causes of the crisis, we explore three potential energy-related causes: (i) the possibility that Russia annexed territory to acquire energy reserves or deny them to Ukraine; (ii) the role of natural gas price disputes between Russia and Ukraine; and (iii) the nature of Russia as a petrostate in facilitating aggressive foreign policy. Only the latter two were significant, and even then they were important in laying the foundations for the conflict rather than triggering the crisis itself. On the question of the so-called energy weapon, we note that whoever tries to employ it faces severe constraints, at least in the short-term. 
Our analysis holds several lessons for policymakers. To begin with, they should avoid overreacting to threats based on the energy weapon, given the practical limits to its use that we have highlighted here. The energy sanctions that have been imposed on Russia, for example, mainly cater to a short-term desire, which is particularly strong in the US, of policymakers wanting to 'do something' following the annexation of Crimea (and in the absence of any desire to pay a real hefty price to support the Ukrainians). Even if those sanctions have been designed in such a way that they do not target Russia's current oil and gas exports (which could undermine Western energy security), they bring about exactly that which policy makers seek to avoid, namely the politicization of energy trade.

A long-term strategy for policymakers in Washington and Europe should be guided by the principles of transparency and market reforms. While stress tests, emergency loans for Ukraine, and other damage control strategies are useful short-term actions to increase the resilience of some vulnerable countries on Europe's eastern flank, they are not substitutes for a long-term strategy of making Eurasian gas trade less opaque and more market conforming. The EU and IMF should continue to leverage their assistance to Ukraine to bring about much needed domestic energy reforms - namely, to restructure state-owned Naftogaz, decontrol domestic gas prices, and introduce legal reforms that foster competition. But the EU can also accomplish a great deal by creating a real internal energy market at home by stimulating the creation of interconnecting pipeline capacity (preferably bidirectional), increasing storage capacity, and boosting 'homegrown' energy sources that simultaneously cut imports and carbon emissions.

Ultimately, the long-term ambition should not be to just stabilize oil and gas trade and investment between exporters, transit countries and consumers. Rather, it should be to live up to the Paris COP2 1 pledge of limiting climate change to "well below $2{ }^{\circ} \mathrm{C}$ ", which effectively implies net zero carbon emissions in the second half of this century. In this context, stable, predictable and transparent energy policies could give investors more planning security and give signposts of where oil and gas demand is heading. Such a regulatory environment should guard against the risk of stranded assets, which are particularly pronounced in the midstream gas (e.g., LNG terminals, gas pipelines) and upstream oil sectors. ${ }^{40}$ As a corollary, it will also make it less likely for oil and gas to play contextual roles in international security crises, as they did in the 2014 Ukraine crisis. 


\footnotetext{
${ }^{1}$ Belyi, Andrei V. "Limitations of resource determinism in international energy studies." Energy Research \& Social Science 12 (2016): 1-4.

${ }^{2}$ Goldthau, A., \& Boersma, T. (2014). The 2014 Ukraine-Russia crisis: Implications for energy markets and scholarship. Energy Research \& Social Science, 3, 13-15.

${ }^{3}$ Naomi O'Leary, "G7 to begin reducing Russian energy dependency - Ed Davey," Reuters, May 6, 2014.

${ }^{4}$ Office of the United Nations High Commissioner for Human Rights, Report on the human rights situation in Ukraine, Dec. 15, 2014

(http://www.ohchr.org/Documents/Countries/UA/OHCHR_eighth_report_on_Ukraine.pdf).

${ }^{5}$ Carol Matlack, "Losing Crimea Could Sink Ukraine's Offshore Oil and Gas Hopes," Businessweek, Mar. 11,
} 2014

${ }^{6}$ William J. Broad, “In Taking Crimea, Putin Gains a Sea of Fuel Reserves," New York Times, May 17, 2014.

${ }^{7}$ State Statistics Committee of Ukraine, All-Ukrainian Population Census, 2001

(http://2001.ukrcensus.gov.ua/eng/results/general/nationality/).

${ }^{8}$ US Energy Information Administration, Technically Recoverable Shale Oil and Shale Gas Resources: An Assessment of 137 Shale Formations in 41 Countries Outside the United States, June 2013

(http://www.eia.gov/analysis/studies/worldshalegas/pdf/overview.pdf).

${ }^{9}$ IEA, World Energy Outlook 2012 (Paris: OECD/IEA), pp. 129-130.

${ }^{10}$ James Henderson, Simon Pirani and Katja Yafimava, "CIS Gas Pricing: Towards European Netback?," in The

Pricing of Internationally Traded Gas, ed. Jonathan P. Stern (Oxford: Oxford University Press), pp. 178-223;

James Henderson, "Does Russia Have A Potent Gas Weapon?," in The Palgrave Handbook of the International Political Economy of Energy, ed. Thijs Van de Graaf, Benjamin K. Sovacool, Arunabha Ghosh, Florian Kern, and Michael T. Klare (Basingstoke: Palgrave MacMillan), pp. 461-486.

${ }^{11}$ Karel Svoboda, "Business as Usual? Gazprom's Pricing Policy Toward the Commonwealth of Independent States," Problems of Post-Communism, November/December 2011, pp. 21-35.

${ }^{12}$ Jonathan P. Stern, The Future of Russian Gas and Gazprom (Oxford: Oxford University Press), 2005.

${ }^{13}$ Will Englund and Kathy Lally, "Ukraine, under pressure from Russia, puts brakes on E.U. deal," Washington Post, Nov. 21, 2013.

${ }^{14}$ Simon Pirani, "Ukraine's imports of Russian gas: How a deal might be reached," Oxford Energy Comment, Oxford Institute for Energy Studies, July 2014 (http://www.oxfordenergy.org/2014/07/ukraines-imports-ofrussian-gas-how-a-deal-might-be-reached/).

${ }^{15}$ Pirani, "Ukraine's imports of Russian gas."

${ }^{16}$ Michael Birnbaum and Carol Morello, "Russia's Gazprom cuts gas to Ukraine in a new phase of the nations' conflict," Washington Post, June 16, 2014.

${ }^{17}$ Jeff D. Colgan, "Petro-Aggression: How Russia’s Oil Makes War More Likely.” Washington Post, Apr. 5, 2014.

${ }^{18}$ Jeff D. Colgan, "Oil and Revolutionary Governments: Fuel for International Conflict," International Organization, October 2010, pp 661-694.

${ }^{19}$ Jeff D. Colgan, Petro-Aggression: When Oil Causes War (Cambridge: Cambridge University Press, 2013).

${ }^{20}$ Colgan, Petro-Aggression; Jeff D. Colgan, "Domestic Revolutionary Leaders and International Conflict," World Politics, October 2013, pp. 656-690.

${ }^{21}$ Pirani, "Ukraine's Imports of Russian Gas."

${ }^{22}$ U.S. Energy Information Administration, Today in Energy, July 23, 2014 (http://www.eia.gov/todayinenergy/detail.cfm?id=17231\#).

${ }^{23}$ Thijs Van de Graaf, "Details of China-Russia Gas Deal Put 'Historic' Agreement in Perspective," World Politics Review, May 28, 2014 (http://www.worldpoliticsreview.com/articles/13810/details-of-china-russia-gasdeal-put-historic-agreement-in-perspective).

${ }^{24}$ Barney Jopson, “US gas boom could be geopolitical weapon," Financial Times, Mar. 6, 2014.

${ }^{25}$ Andrew Critchlow, "US fires warning shot at Russia with gas export deal," The Telegraph, Mar. 24, 2014.

${ }^{26}$ Fraser Nelson, "America has a new weapon to use against Russia - the E-bomb," The Telegraph, Mar. 6, 2014.

${ }^{27}$ US Federal Energy Regulatory Commission, Existing North American LNG Import/Export Terminals, Octy. 13, 2016 (https://www.ferc.gov/industries/gas/indus-act/lng/lng-existing.pdf).

${ }^{28}$ US Department of Energy, LNG Monthly, Nov. 15, 2016

(http://energy.gov/sites/prod/files/2016/11/f34/LNG\%202016_0.pdf).

${ }^{29}$ Michael Levi, “An Energy Weapon vs. Russia?” Mar. 5, 2014 (http://blogs.cfr.org/levi/2014/03/05/an-energyweapon-vs-russia/).

${ }^{30}$ Meghan O’Sullivan, “A Better Energy Weapon to Stop Putin,” BloombergView, Mar. 11, 2014.

${ }^{31}$ US Department of the Treasury, Directive 4 Under Executive Order 13662, Sep. 12, 2014

(http://www.treasury.gov/resource-center/sanctions/Programs/Documents/eo13662_directive4.pdf); Council 
Regulation (EU) No 960/2014 of 8 September 2014 amending Regulation (EU) No 833/2014 concerning restrictive measures in view of Russia's actions destabilising the situation in Ukraine (http://eur-

lex.europa.eu/legal-content/EN/TXT/?uri=uriserv:OJ.L_.2014.271.01.0003.01.ENG).

${ }^{32}$ International Energy Agency, Energy Policies Beyond IEA Countries - Russia 2014 (Paris: OECD/IEA).

${ }^{33}$ John Kemp, "EU energy restrictions on Russia are mostly 'sanctions theatre'," Reuters, Aug. 4, 2014.

${ }^{34}$ Thijs Van de Graaf, "The 'Oil Weapon' Reversed? Sanctions Against Iran and U.S.-EU Structural Power," Middle East Policy, Fall 2013, pp. 145-163.

${ }^{35}$ Jeff D. Colgan, "Could Energy Sanctions Against Russia Work?,” May 4, 2014

(http://www.lawfareblog.com/2014/05/the-foreign-policy-essay-could-energy-sanctions-on-russia-work/).

${ }^{36}$ Andreas Goldthau and Tim Boersma, "The Ukraine Challenge and Europe's Energy Needs Collide," The

National Interest, Sep. 10, 2014.

${ }^{37}$ World Bank, Global Economic Prospects: Spillovers Amid Weak Growth. January 2016. Washington D.C.:

World Bank Group.

${ }^{38} \mathrm{http} / / /$ blogs.wsj.com/emergingeurope/2014/10/10/hungary-to-store-natural-gas-for-russias-gazprom/

${ }^{39}$ Karel Beckman, “Can Nord Stream 2 be Stopped?” Energy Post, April 14, 2016,

http://www.energypost.eu/can-nord-stream-2-stopped/.

${ }^{40}$ Presentation by Christophe McGlade, IEA, at the international conference on "Fossil Fuels and Climate

Change", Queen's College, Oxford, UK, September 27 $7^{\text {th }}, 2016$. 